\title{
Critical Minerals: Current Challenges and Future Strategies
}

\author{
Vikas Agrawal and Shikha Sharma* \\ Department of Geology \& Geography, West Virginia University, USA
}

Submission: February 26, 2021; Published: March 09, 2021

*Corresponding author: Shikha Sharma, West Virginia University, Department of Geology \& Geography, 330 Brooks Hall, 98 Beechurst Ave. Morgantown, WV 26506, USA

\section{Abstract}

The demand for Critical Minerals (CMs) is soaring because of their extensive use in renewable energy generation, energy storage, energy transmission, scientific instrumentation, and a wide range of communication, military, and transport technologies. However, the supply of CMs faces several critical challenges like

- $\quad$ a few countries have a monopoly in mining and processing of particular CMs

- $\quad$ variable concentration and deposit grades in different geographical areas

- $\quad$ inadequate assessment of resources

- inefficient mining, extraction, and processing technologies,

- $\quad$ little to no recycling

- $\quad$ limited workforce and

- $\quad$ severe environmental and human health impacts associated with CM mining, processing, and production.

For environmentally sustainable development of the CM industry, countries need to make significant investments in advanced competitive research, development of efficient environment-friendly mining, extraction, and processing technologies, creation of robust environmental policy frameworks, and workforce development solutions.

Keywords: Critical minerals; Rare earth elements; Geopolitics; Mining; Extraction; Processing; Recycling; Environmental impacts; Environmental remediation

\section{Introduction}

A "critical mineral" is defined as a substance that serves an essential function in manufacturing product(s), whose supply chain is vulnerable to disruption, and the absence of which could lead to substantial consequences for the country's economy or national security $[1,2]$. The demands of CMs, including lithium, nickel, cobalt, graphite, and rare earth elements (REEs), are soaring because of their essential role in clean energy transmission and storage technologies. Clean-energy technologies generally require more CMs than conventional fossil fuel-based technologies. For instance, an electric vehicle uses five times the amount of minerals compared to a combustion-engine vehicle, and a windmill requires eight times the minerals needed by a gas-fired power plant with the same capacity [3]. The push for 'greener' energy generation (wind, solar and geothermal) and related storage solutions could result in a demand of 3 billion tons of minerals and metals and a $500 \%$ increase in the production of CMs such as graphite, lithium, and cobalt and a by 2050 [4].

One of the biggest challenges is that the production of different CMs is concentrated in a few countries. For instance, $>80 \%$ of Pt is produced by South Africa and Zimbabwe, Australia and Chile produce $>75 \%$ of all $\mathrm{Li}, 75 \%$ of $\mathrm{Co}$ is produced by Dominion Republic of Congo (DRC) [5-9]. For a few other CMs, a single country controls more than $50 \%$ of global production (e.g., China for REEs, Australia for Li, DRC for Co, South Africa for Pt) [6]. The US currently has no domestic production for fourteen out of thirty-five CMs and produces less than $50 \%$ of net 
demand for seventeen other CMs [10]. Due to such low in-house production, the US is mainly dependent on imports from other countries to meet its demand (e.g., 80\% REEs imported directly from China). The increasing demands of CMs could drive global geopolitics and result in trade wars in the near future. Therefore, individual countries need to develop and enhance their national $\mathrm{CM}$ resources and supplies in an environmentally responsible manner.

\section{Strategies for Developing CM Industries}

Countries with $\mathrm{CM}$ resources need to make serious investments in developing a sustainable supply chain for CMs and creating future growth capacity. The governmental agencies play a crucial role in evaluating the $\mathrm{CM}$ resources and funding the academia-industry consortia for applied and basic research related to CM and REEs. There is a need to improve understanding of the geological and geochemical controls on CM enrichment in particular basins, rocks, fluids, etc. For example, coal and coal byproducts (including run-of-mine coal, coal refuse, coal ash, acid mine drainage) are critical resources for CM and REEs. However, there are only a few studies on efficiently extracting CM and REE from these resources [11-13]. There is a vital need to develop geological models of ore occurrence, mineral processing, and extractive metallurgy [5]. Funding in geosciences, geochemistry, and chemical engineering should target the development of new tools for the exploration and efficient extraction of CMs. Further, new investments should be made in technologies that treat the leftover material from mining as a resource, develop urban mining techniques and find substitutes of CMs that are low in abundance [3].

Another useful strategy would be the recovery of CMs via effective recycling of industrial and electronic waste. It is estimated that each year $\sim 50$ million metric tons of e-waste are disposed in landfills worldwide, and only $12.5 \%$ of e-waste is currently being recycled for all metals [14]. Studies on life cycle assessments of CMs such as REEs have indicated that recycling electronic waste could be an encouraging supplement to conventional production processes [15]. An example of recycling iPhones can easily demonstrate the effectiveness of recycling in meeting the CM demands. Recycling of 10,000 iPhones has the potential to yield $190 \mathrm{~kg}$ of aluminum, $77 \mathrm{~kg}$ of cobalt, $71 \mathrm{~kg}$ of copper, $9.3 \mathrm{~kg}$ of tungsten, $4.2 \mathrm{~kg}$ of tin, $1.1 \mathrm{~kg}$ of REE, $0.75 \mathrm{~kg}$ of silver, $0.18 \mathrm{~kg}$ of tantalum, $0.097 \mathrm{~kg}$ of gold and $0.01 \mathrm{~kg}$ of palladium [16]. Boosting recycling technologies for lithium-ion batteries [9] could also contribute to $\mathrm{CM}$ and $\mathrm{REE}$ recovery from waste.

There is also a need to develop a skilled workforce to generate and maintain sustainable CM supply chains. Each CM ore or deposit is unique and requires different mining and processing technology. Therefore, even if we have sufficient resources, we need skilled scientists/workforce to resolve these complex issues. However, in countries like the US, there has been a steady decline in mining industry employment from 25,000 employees
$(3,750$ with science degrees) in the 1980 s to 1,500 with only 250 employees holding science degress [5]. Therefore, it is essential to create a workforce pipeline by engaging and training students at the college level in CM exploration, mining, and processing.

Finally, to promote the engagement of private companies in the CM industry, the governments should consider stockpiling, tax credits, and loan guarantees to reduce the risks associated with CM mining and processing. These targeted investments in CM research, mining, production, waste recovery, and recycling could potentially change the $\mathrm{CM}$ economics of countries and make them competitive with large producers like China.

\section{Limiting Environmental Impacts of CM Industries}

Although CMs support developing green energy technologies, their extraction, separation, and development can severely impact the environment and human health. The severity of these impacts can vary with mining operations, type of ore, processing of the mineral ore, local geology, and hydrogeology of the area. For example, lithium mining, processing, and manufacturing of lithium-ion batteries could have significant environmental impacts such as water depletion and pollution, increased toxicity on plants and animals, land subsidence, carbon emissions [1719]. The process of REE extraction has also been reported to use harmful chemicals that generate high volumes of solid waste and wastewater [14]. Dumping of e-waste and improper treatment methods has been shown to leach large amounts of CMs and several other toxic elements in the soil and groundwater, especially in developing countries like Ghana, India, and China [20-22]. Cobalt mining in DRC has been criticized for using child labor and other irresponsible mining practices [9]. A biomonitoring study of cobalt mining in DRC reveals a substantial exposure of Co, especially in children, and the urinary concentrations of Co were found to be the highest ever reported for a general population [23]. These case studies indicate that high concentrations of CMs can be released in soil and water during CM mining and processing. However, there is still minimal understanding of the impact of the majority of the CMs on human health [14]. For instance, the maximum acceptable limits for CMs and REE in drinking water are still not available from environmental agencies and international health organizations. Therefore, is a critical need for regulatory agencies to develop and enforce permissible limits of CMs in water and soil. The impact of CM mining on sediment loads in regional watersheds and associated adverse effects on local flora and fauna also need to be assessed. Also, comprehensive remediation plans need to be implemented to effectively treat acid mine discharges and fully restore the mined areas. In addition, fine particulates, aerosols, volatiles and radioactive materials need to be monitored and regulated in CM and REE mining and processing facilities to limit human exposure and associated health hazards. Countries need to develop robust environmental policy frameworks to ensure that the development of CM industry creates no major threats to the environment and human health. 


\section{Concluding Remarks}

The development of an environment-friendly sustainable supply of CMs faces several challenges. The governmental agencies, industries, academicians, and environmental advocacy groups need to work together to ensure appropriate policies and incentives are put in place to develop the CM industry. The government needs to invest in research, infrastructure, and workforce development to address the mining, processing, and maintaining supply chains of important CMs. The governmental agencies also need to ensure that adequate environmental policy and regulatory framework are developed and enforcement plans are put in place before expanding the CM industry. The industryacademia consortiums need to work together to explore innovative methods for improving the efficiency of mining, extraction, production, and recycling of CMs and ensuring these methods have minimal environmental impacts. This multi-stakeholder approach will resolve complex issues surrounding the economic development of $\mathrm{CM}$ industries and create comprehensive environmental checks and solutions.

\section{References}

1. Fortier SM, Nassar NT, Lederer GW, Brainard J, Gambogi J, et al. (2018) Draft critical mineral list-Summary of methodology and background information-US Geological Survey technical input document in response to Secretarial Order No. 3359. U.S. Geological Survey, Reston, VA, p. 15.

2. (2017) A Federal Strategy to Ensure Secure and Reliable Supplies of Critical Minerals. Federal Register.

3. Willige A (2020) What to know about critical minerals - the key to our clean energy future. World Economic Forum.

4. Hund K, La Porta D, Fabregas TP, Laing T, Drexhage J (2020) Minerals for climate action: the mineral intensity of the clean energy transition. World Bank (2020).

5. Fromer N, Eggert RG, Lifton J (2011) Critical materials for sustainable energy applications.

6. Kim TY, Karpinski M (2020) Clean energy progress after the Covid-19 crisis will need reliable supplies of critical minerals. International Energy Agency.

7. Castilloux R (2019) Rare Earth Elements: Market Issues and Outlook. Adamas Intelligence.

8. Dudley B (2019) BP Statistical Review of World Energy.
9. Ladislaw S, Carey L, Bright H (2019) Critical minerals and the role of US mining in a low-carbon future. CSIS Briefs.

10. Addressing the Threat to the Domestic Supply Chain from Reliance on Critical Minerals from Foreign Adversaries and Supporting the Domestic Mining and Processing Industries. Federal Register.

11. Zhang W, Noble A, Yang X, Honaker RA (2020) Comprehensive Review of Rare Earth Elements Recovery from Coal-Related Materials. Minerals 10(5): 451.

12. Zhang W, Honaker R (2020) Characterization and recovery of rare earth elements and other critical metals ( $\mathrm{Co}, \mathrm{Cr}, \mathrm{Li}, \mathrm{Mn}, \mathrm{Sr}$, and V) from the calcination products of a coal refuse sample. Fuel 267: 117236.

13. Taggart RK, Hower JC, Hsu Kim H (2018) Effects of roasting additives and leaching parameters on the extraction of rare earth elements from coal fly ash. International Journal of Coal Geology 196: 106-114.

14. Balaram V (2019) Rare earth elements: A review of applications, occurrence, exploration, analysis, recycling, and environmental impact. Geoscience Frontiers 10(4): 1285-1303.

15. Sprecher B, Xiao Y, Walton A, Speight J, Harris R, et al. (2014) Life Cycle Inventory of the Production of Rare Earths and the Subsequent Production of NdFeB Rare Earth Permanent Magnets. Environ Sci Technol 48(7): 3951-3958.

16. Staub C (2018) Apple rolls out robot for iPhone dismantling. E-Scrap News.

17. Saucier JH (2021) Are Critical Minerals the New Oil and Gas? AAPG EXPLORER.

18. Kaunda RB (2020) Potential environmental impacts of lithium mining. Journal of Energy \& Natural Resources Law 38(3): 237-244.

19. Wanger TC (2011) The Lithium future-resources, recycling, and the environment. Conservation Letters 4(3): 202-206.

20. Agyei Mensah S, Oteng Ababio M (2012) Perceptions of health and environmental impacts of e-waste management in Ghana. International journal of environmental health research 22(6): 500-517.

21. Needhidasan S, Samuel M, Chidambaram R (2014) Electronic wastean emerging threat to the environment of urban India. Journal of Environmental Health Science and Engineering 12(1): 1-9.

22. Leung A, Cai ZW, Wong MH (2006) Environmental contamination from electronic waste recycling at Guiyu, southeast China. Journal of Material Cycles and Waste Management 8: 21-33.

23. Banza CLN, Nawrot TS, Haufroid V, Decree S, Putter TD, et al. (2009) High human exposure to cobalt and other metals in Katanga, a mining area of the Democratic Republic of Congo. Environmental Research 109: 745-752. 

CC (-) This work is licensed under Creative BY DOI:10.19080/IJESNR.2021.27.556215
Your next submission with Juniper Publishers will reach you the below assets

- Quality Editorial service

- Swift Peer Review

- Reprints availability

- E-prints Service

- Manuscript Podcast for convenient understanding

- Global attainment for your research

- Manuscript accessibility in different formats

( Pdf, E-pub, Full Text, Audio)

- Unceasing customer service

Track the below URL for one-step submission https://juniperpublishers.com/online-submission.php 